\title{
Simulating the Upper St. Johns River for Extreme Events
}

\author{
Christopher J. Brown ${ }^{1}$ and Amanda E. Tancreto ${ }^{2}$ \\ ${ }^{1}$ University of North Florida, Jacksonville, Florida; ${ }^{2}$ U.S. Army Corps of Engineers, Jacksonville, Florida.
}

\begin{abstract}
The St. Johns River is one of the most important river systems in Florida. The watershed begins in East Central Florida and discharges to the Atlantic Ocean east of Jacksonville, Florida. The watershed is susceptible to large rainfall events including tropical storms and hurricanes and is topographically flat such that flooding is a real concern.

The Upper St. Johns River Basin (USJRB) encompasses an area of approximately $4530 \mathrm{~km}^{2}$. USJRB mainly comprises marsh and agricultural land types including man-made storage areas used for flood control and environmental management, and includes numerous water control structures. The Middle St. Johns River Basin (MSJRB) is downstream of the USJRB and covers an area of approximately $3100 \mathrm{~km}^{2}$. The land use in this region is dominated by more urbanized areas including parts of Orlando. Recently, researchers at the University of North Florida developed a preliminary HEC-HMS rainfall-runoff model of the USJRB and a portion of the MSJRB. The model domain covers roughly $5200 \mathrm{~km}^{2}$ and includes numerous subbasins. The model was calibrated and verified against observed data recorded between 2007 and 2011 and including a large tropical storm event.

This new study expands the use and scope of the model by examining extreme rainfall events and resulting flows that may occur in the future under possible climate change scenarios. First, the model is used to simulate a hypothetical probable maximum precipitation (PMP) event. Then, the model is used to simulate the same PMP event but with future climate change forcing added. Lastly, the model is used to simulate two $100 \mathrm{y}$ rainfall events occurring in the same week. This study provides the simulation results, compares them to historical flow data at key locations within the model domain, and then finishes with a discussion of water resources planning considerations for the future.
\end{abstract}

\section{Methodology}

\subsection{Overview}

The University of North Florida (UNF) was tasked by the St. Johns River Water Management District (SJRWMD) to complete a research study regarding the "economic valuation of the St. Johns River" as part of SJRWMD research grant 27884. This study focused upon ecological services that the St. Johns River provides for the citizens of Northeast Florida (Hackney 2015). One portion of the study was devoted to an assessment of flood mitigation services provided by wetlands in the St. Johns River watershed. In order to complete the assessment, a series of existing numerical models were integrated to enable simulations of the entire watershed, including hydrologic drivers such as rainfall, runoff, evapotranspiration, groundwater baseflow and tidal effects. The overall watershed was divided into three primary components including:

- the upper basin and a portion of the middle basin; . the majority of the middle basin; and,
- the lower basin.

Figure 1 below shows the general location of the project study area and three simulation basin areas. The portion of the entire model domain that is the focus of this paper and is discussed herein is also illustrated by the red triangle and light red hatching.

UNF was responsible for simulating the upper basin, a small southern portion of the middle basin, and the lower basin. The University of Central Florida (UCF) was assigned the central portion of the study area which included the remaining portions of the middle basin. This paper will focus upon the upper basin area primarily although the model domain includes a small portion of the middle basin also (as shown on Figure 1 by red hatching). The UNF research team simulated its assigned study area using the public domain hydrology code Hydrologic Engineering Center, Hydrologic Modeling System or HEC-HMS (USACE 2000; Scharffenberg and Fleming 2010). This paper will discuss the model development and calibration effort followed by its use for new research regarding extreme precipitation events. This paper will provide an abbreviated

Brown, Christopher J. and Amanda E. Tancreto. 2016. Simulating the Upper St. Johns River for Extreme Events.

Journal of Water Management Modeling 25:C412. https://doi.org/10.14796/JWMM.C412 (c) CHI 2016. www.chijournal.org ISSN 2292-6062. 
summary of the extensive model development and calibration effort herein but the reader is referred to Tancreto (2015) for complete details regarding the model. The complete thesis study can be downloaded at http://digitalcommons.unf.edu/ etd $/ 584 /$.

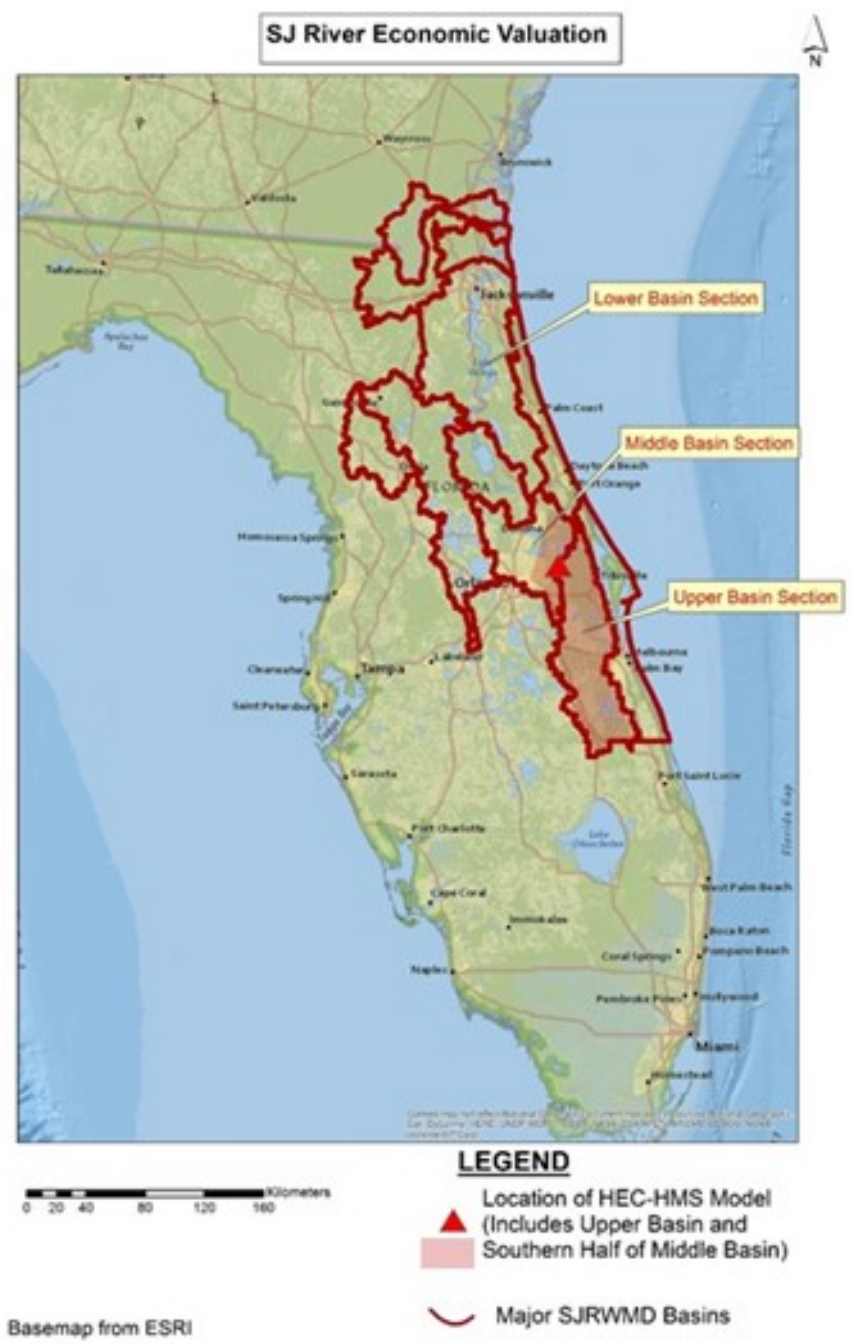

Figure 1 Project study area in Northeast Florida along with three simulation areas.

\subsection{HEC-HMS Model Development}

The upper St. Johns River basin (upper basin) encompasses an area of approximately $4530 \mathrm{~km}^{2}$. The upper basin includes marsh and agricultural land types with numerous artificial storage areas used for flood control and environmental management. The middle St. Johns River basin (middle basin) is downstream of the upper basin and covers an area of approximately $3100 \mathrm{~km}^{2}$. The land use in this region is dominated by more urbanized areas including parts of Orlando, Florida. The UNF research team developed an HEC-HMS model of the entire upper basin and one portion of the middle basin. The model domain covers $\sim 5200 \mathrm{~km}^{2}$ and includes numerous subbasins, reservoirs and channel reaches. The model is designed principally to estimate runoff from the various basins and route the water along the St. Johns River floodplain to the model outlet. The model estimates the discharge for all model elements and the stage in certain storage areas and lakes with a reasonable degree of accuracy. However, the model is not ideally suited for evaluations of the main stem river stage or first floor flood elevations in the same area. Generally, HEC-HMS is not designed to incorporate backwater boundary effects directly and it cannot easily include tidal effects. Therefore for the St. Johns River Economic Study, HEC-HMS was not used in the northern reaches of the middle basin or the lower basin. For the larger basin-wide assessment study, the HEC-HMS model provided boundary inflows to a Soil Water and Assessment Tool (SWAT) (Arnold and Allen 1993; Arnold and Fohrer 2005) model developed by UCF covering a majority of the middle basin. UCF in turn provided boundary inflows to a three-dimensional hydrodynamic AdCirc (Luettich and Westerink 1991) model of the lower basin. The AdCirc model was used to evaluate flood storage ecological benefits in wetland areas in the lower basin.

HEC-HMS is a widely accepted code and has been used in many model studies throughout the United States (Anderson et al. 2002; Knebl et al. 2005). It is ideally suited for evaluating large scale changes in precipitation input or land use changes in a model domain. For this study, the model domain includes subbasin delineation adopted from the U.S. Army Corps of Engineers (USACE) and includes the SJRWMD defined planning units of Fort Drum Creek, Blue Cypress Creek, Fellsmere, Jane Green Creek, St. Johns Marsh, Lake Poinsett, Toschatchee, and Puzzle Lake. The model domain also includes the Econlockhatchee River planning unit located in the middle basin.

Each planning unit consists of multiple subbasins (e.g. smaller watersheds), which subdivide each planning unit into more detailed areas for hydrologic modeling purposes. These subbasins were delineated using topographic divides, artificial structures (e.g. levees and drainage canals), and drainage paths. In some cases, very small subbasins were combined together for ease of modeling and where such a simplification was not expected to change simulation results significantly. Generally, this approach was deemed satisfactory as the focus of the UNF research was on large scale processes. Figure 2 shows all of the subbasins incorporated into the UNF model by Tancreto (2015). Figure 2 also highlights six existing stream gauge locations that will be discussed further in this study in regard to model calibration and new simulation results assessing extreme precipitation events. Figure 2 highlights the far southern Fort Drum subbasin, Blue Cypress subbasin, and Penneywash subbasin as well as main stem river locations at U.S. 192, S.R. 520, and at the inlet to Lake Harney. 


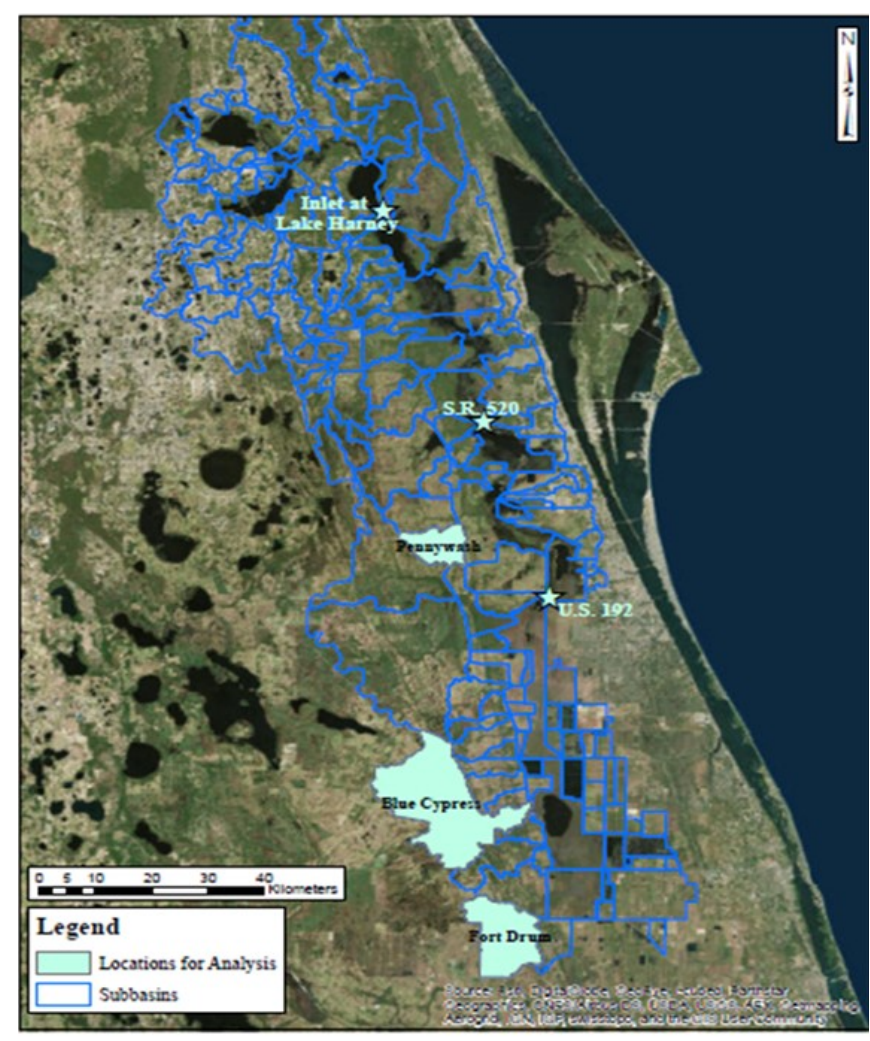

Figure 2 Project study showing subbasins and the locations of key project discharge gauges.

The subbasin delineations were developed based on projects completed within the upper basin as of the project year of 2008. Therefore the Three Forks Marsh Conservation Area, which was constructed after 2008, is not included in the model. The implications of this omission are discussed in Section 2 of this paper. For the basin land use, 1995 datasets were utilized. Use of the 1995 base year land use permitted the model to be used for simulation of a wide array of historic storms, as well as to simulate the effects of ongoing land use change in the watershed. With the exception of the Three Forks project addition, the upper basin has not changed appreciably between 1995 and 2015. The overall middle basin delineation has not changed significantly since 1995 but flow patterns and runoff lag time have been altered due to the continued increases in urban development. This has caused disruptions in the historical runoff conveyance due to additional drainage ditching, new retention ponds and the inclusion of increased impervious areas. Therefore the model should be used with some caution for future studies involving the middle basin portion of the model.

HEC-HMS computes outflow by subtracting infiltration and temporary storage losses, transforming excess precipitation into output hydrographs, adding baseflow, and subtracting evapotranspiration from the input precipitation data that is applied to each subbasin. The code also can route water through simple reaches enabling hydrologic connection of the entire model domain. The code has many choices of algorithms to compute infiltration losses as well as transform the remaining excess pre-cipitation (e.g. runoff) into a hydrograph. For the UNF model, the United States Department of Agriculture Soil Conservation Survey (SCS) curve number method (U.S. Department of Agriculture Soil Conservation Service 1972) was utilized for infiltration losses and the associated SCS unit hydrograph method was used for computing the outflow hydrograph in each subbasin.

The land use and land cover data were downloaded from the SJRWMD for the project land use baseline year 1995 (SJRWMD 2014). Data were available for each Florida county, and therefore only counties associated with the project area were downloaded. Each data set was imported into ArcGIS as a shape file until the entire project area contained land use data. Within each shapefile the land use data were classified using the Florida Land Use and Cover Classification System (FLUCCS), with >100 different land cover types included (SJRWMD 2014). The land use data was then combined with published soil cover data in Florida or the state soil geographic soil classification system (STATSGO) soil group classification data. These data were imported into ArcGIS as a shapefile and combined with the land use data to calculate an appropriate curve number. Then, for each subbasin, an overall weighted curve number was calculated based upon the percent coverage of each soil type and land use type.

To accurately represent the hydrologic response of each subbasin to a precipitation event, a hydrograph for each subbasin, based on the time of concentration and lag time, was calculated. Many empirical methods are available to estimate the basin lag time or time of concentration. For this study, four different methods were used and averaged to determine a mean value as well as a possible range of the input value. The Natural Resources Conservation Service (NRCS, formerly Soil Conservation Service, SCS) developed two methods similar to the original base SCS method provided as a default in HEC-HMS. These are discussed by Li and Chibber (2008) and Sharifi et al. (2011). Another common methodology recommended by the NRCS is the method known as the velocity method where the time of concentration may be calculated using the Manning's kinematic solution for sheet flow, shallow concentrated flow, and open channel flow (U.S. Department of Agriculture Natural Resources Conservation Service 2010). Lastly, a modified version of the Snyder lag time equation was also utilized. This form of the lag equation was originally developed by Snyder but was later revised by USACE and the U.S. Bureau of Reclamation (City and County of Sacramento 1996).

Precipitation input data for the study was compiled from two different sources. First existing rain gauge data was assembled from throughout the study area. Gauges were chosen based upon geographic coverage but also on whether they provided data for the various calibration and validation storms used for the study. Besides the rain gauge data, next generation radar (NEXRAD) based rainfall data was also collected and used in the study. Both datasets were used in two different complement-ary versions of the model, as one of the primary research goals in 2015 was to compare model calibration statistics with each 
precipitation data type in order to determine the relative value of each for model development in the flat subtropical watershed studied. Further discussion of this effort and the overall results can be found in Tancreto (2015). In general, once each model was calibrated using either rain gauge or NEXRAD data, either model was satisfactory for use in predictive simulations, as comparable model discharges are very similar. For this paper the model version with rain gauge data was used for predictive simulations.

Finally, an overall routing method had to be chosen from the available options in HEC-HMS. The hydrologic routing method chosen for the model was the Muskingum-Cunge routing method because it can be used in reaches with a small slope, and is based on the conservation of mass and the diffusion representation of the conservation of momentum (Scharffenberg and Fleming 2010). Further, the Muskingum-Cunge method was chosen based on the following model criteria:

- minimal observed hydrograph data available in the flow way for calibration;

- flood wave will enter floodplain; and

- channel slopes are $<0.004$.

After all of the model inputs were included in the model and the initial model compiled successfully, model calibration and validation were completed. The model was calibrated and validated against observed stream and river flow data recorded between 2007 and 2011 and including a large tropical storm event.

\subsection{HEC-HMS Calibration and Validation}

Four different simulation periods were chosen for the calibration and validation efforts. These include:

- August 2008: calibration;

- October 2007: validation;

- March 2010: validation; and

- October 2011: validation.

The smallest precipitation event was in October 2007, which was estimated to have a short recurrence interval of $<1 \mathrm{y}$. This storm would be more representative of a routine average wet season event. From a review of detailed NEXRAD data during the March 2010 event, it was determined that this event was approximately a $1 \mathrm{y}$ recurrence interval. The simulation events of August 2008 and October 2011 included much longer recurrence interval events, ranging between $5 \mathrm{y}$ and $25 \mathrm{y}$ recurrence interval for the $24 \mathrm{~h}$ storm and between $10 \mathrm{y}$ and $25 \mathrm{y}$ recurrence interval for the $48 \mathrm{~h}$ storm. Overall, the calibration and validation periods simulate storm events covering a wide range of recurrence intervals and time of year. The August 2008 timeframe also included the landfall of tropical storm Fay with a few small subbasins receiving $>50 \mathrm{~cm}$ precipitation over $3 \mathrm{~d}$.

Both the calibration and validation efforts used thirteen existing stream gauges in the watershed for comparison purposes. For this study, results are shown at six of the most important gauges which were selected because they are representative of both smaller subbasin responses as well as the hydrologic response of the main stem river. Figure 2 above depicts the location of all six gauge locations discussed herein. Three of the gauges (Penneywash Creek, Blue Cypress and Fort Drum) are located at the outlets of key subbasins in the upper basin. The remaining three gauges used are located on the main stem of the St. Johns River (US 192, FL 520 and the inlet to Lake Harney).

To ensure that the model simulates the proper physical mechanisms and environmental processes, the model was calibrated to the observed conditions during the period 2008-08-01 to 2008-10-08. The process for calibration includes:

1. Establishing the model parameters and determining those that will be changed for calibration;

2. Defining the observed values and locations which the model results should reproduce;

3. Determining statistical goals for the model to be considered calibrated; and

4. Performing iterative solutions and the adjustment of parameters until the calibration goals have been met.

The primary goal of the calibration process is to match the simulation results to the observed gauge data as closely as possible. The modeled error, as measured by statistical analysis, should be minimized by the calibration process. For calibration and validation efforts, several different statistics were used to assess the overall goodness of fit between simulated discharge and observed discharge. This comparison was completed using three different statistical measures: the correlation coefficient, the coefficient of determination and the Nash-Sutcliffe efficiency coefficient. The coefficient of correlation $(r)$ measures the strength and direction of the linear relationship between variables of the measured gauge data and simulation data. The calculated $r$ value will be between -1 and 1 , with 0 representing no correlation. The coefficient of determination $\left(r^{2}\right)$ gives the variance of the data and assesses a goodness of fit at each calibration point for the model. The equation for $r^{2}$ is provided below in Equation 1. The coefficient of determination is between 0 and 1, with 1 indicating a perfect fit with all variation explained. As the coefficient approaches 1 , the overall ability of the model to more accurately produce better predictive simulations increases.

$$
r^{2}=\left(\frac{\sum_{i=1}^{n}\left(O_{i}-\bar{O}\right)\left(S_{i}-\bar{S}\right)}{\sqrt{\sum_{i=1}^{n}\left(O_{i}-\bar{O}\right)^{2}} \sqrt{\sum_{i=1}^{n}\left(S_{i}-\bar{S}\right)^{2}}}\right)^{2}
$$

where:

$$
\begin{aligned}
& O_{i}=\text { the observed discharge data on the ith day, } \\
& S_{i}=\text { the simulated discharge data on the ith day, } \\
& \bar{O}=\text { the observed mean value, } \\
& \bar{S}=\text { the simulated mean value, and } \\
& n=\text { the number of observations. }
\end{aligned}
$$
and Sutcliffe 1970) is a normalized statistic that determines the relative magnitude of the residual variance compared to the measured data variance and indicates how well the plot 
of the observed data versus the simulated data fits the 1:1 line (Wang et al. 2009). The NSE equation is shown in Equation 2.

$$
N S E=1-\frac{\sum_{i=1}^{n}\left(O_{i}-S_{i}\right)^{2}}{\sum_{i=1}^{n}\left(O_{i}-\bar{O}\right)^{2}}
$$

where:

NSE = the Nash-Sutcliffe efficiency coefficient.

The coefficient of determination and NSE results for the 2008 calibration event and 2010 validation event are shown in Table 1 and Table 2 respectively. A detailed discussion of these results and the other validation periods is available in Tancreto (2015).

Table 1 Calibration goodness of fit results for 2008.

\begin{tabular}{lcc}
\hline \multicolumn{1}{c}{ Gauge Location } & $r^{2}$ & NSE \\
\hline Fort Drum & 0.89 & 0.85 \\
Blue Cypress & 0.84 & 0.84 \\
Penneywash & 0.86 & 0.79 \\
US 192 & 0.88 & 0.86 \\
FL 520 & 0.98 & 0.98 \\
Inlet Lake Harney & 0.93 & 0.90 \\
\hline
\end{tabular}

Table 2 Validation goodness of fit results for 2010.

\begin{tabular}{lcc}
\hline \multicolumn{1}{c}{ Gauge Location } & $r^{2}$ & NSE \\
\hline Fort Drum & 0.89 & 0.85 \\
Blue Cypress & 0.91 & 0.86 \\
Penneywash & 0.85 & 0.85 \\
US 192 & 0.96 & 0.98 \\
FL 520 & 0.97 & 0.96 \\
Inlet Lake Harney & 0.95 & 0.87 \\
\hline
\end{tabular}

Based upon the goodness of fit results, both the calibration model and 2010 validation model replicate observed discharges with a high degree of accuracy. The $r^{2}$ values are $>0.84$ and the NSE values are all $>0.79$ which suggests a strong fit between the simulation results and observed data.

\subsection{Simulation of Extreme Precipitation Events}

With the calibrated and validated model, the UNF research team went on to complete some new research work in 2016. This research effort focuses upon the simulation of extreme storm events in the upper basin. Using the model, the UNF team developed three different simulations using different large or extreme precipitation events that could occur in the watershed.

The first event that was simulated was the application of the $24 \mathrm{~h}$ probable maximum precipitation (PMP) across the model domain. The PMP event is the largest precipitation that can ever be expected for a given region for worst case soil moisture conditions combined with optimal meteorological conditions (Schriener and Riedel 1978). The SJRWMD recommends use of the PMP in certain conditions: "Where substantial risk of loss of life exists, it is appropriate to design a structure against what appears to be the worst possible condition" (SJRWMD 2010).
This project area, $\sim 5200 \mathrm{~km}^{2}$, covers a large portion of East Central and Northeast Florida. Using procedures outlined in HMR 51 (Schriener and Riedel 1978), the raw 24 h PMP precipitation was adjusted to the basin size. Essentially, as the basin size gets larger, the mean precipitation intensity across the entire basin gets smaller. The PMP $24 \mathrm{~h}$ event for Florida is recommended to range from $\sim 120 \mathrm{~cm}$ for a $26 \mathrm{~km}^{2}$ basin to $45 \mathrm{~cm}$ for a $26000 \mathrm{~km}^{2}$ basin. For this study, a value of $\sim 71 \mathrm{~cm}$ was used as input precipitation across the watershed. Figure 3 shows how the precipitation value was estimated from HMR 51 data.

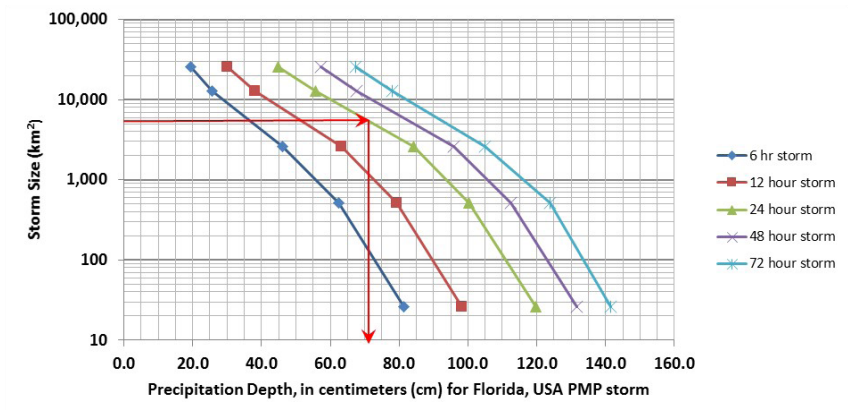

Figure 3 Selection procedure for $24 \mathrm{~h}$ PMP event.

The second event that was simulated was a modification of the $24 \mathrm{~h}$ PMP to account for possible climate change variations that are underway in the south-eastern United States. Generally, scientists believe that climate change in the study area may result in more intense precipitation and possibly more frequent precipitation events. With these considerations in mind and based upon some engineering judgment, the PMP precipitation was increased by $5 \%$ to account for these possible variations.

The third event was the rare occurrence of back-to-back $100 \mathrm{y}$ return frequency events in the same week. Perica et al. (2013) completed an up-to-date precipitation frequency analysis of Florida and other south-eastern states. They examined recurrence intervals from 1 y to $1000 \mathrm{y}$ of various durations. The SJRWMD also has recommended precipitation totals for various recurrence intervals but the UNF researchers felt that Perica et al. (2013) provides the most up-to-date estimates. For this study, the UNF research team applied two $24 \mathrm{~h} 100$ y precipitation events within $7 \mathrm{~d}$ based upon the Perica et al. (2013) dataset.

\section{Results and Discussion}

\subsection{The $24 \mathrm{~h}$ PMP Event}

The PMP precipitation totals for Florida are the highest estimates in the continental United States, outside of mountainous zones, subject to orographic precipitation events. Florida has been subjected to many large precipitation events tied to tropical storms and hurricanes. The largest such event on record is the Yankeetown, Florida extreme storm which occurred from 1950-09-03 to 1950-09-07. This hurricane, named Easy, provided one of the largest observed precipitation depths ever recorded in the United States for watershed areas from $26 \mathrm{~km}^{2}$ to $5200 \mathrm{~km}^{2}$ for $18 \mathrm{~h}$ to 
$72 \mathrm{~h}$ duration (SJRWMD 2010). For the size of the present model domain $\left(\sim 5200 \mathrm{~km}^{2}\right)$, Easy produced $67 \mathrm{~cm}$ precipitation in $24 \mathrm{~h}$. As described above, HMR51 procedures resulted in a PMP event size of $71 \mathrm{~cm}$, or slightly larger than Easy.

For the PMP event, the calibrated model period was used and modified. For comparison purposes, the antecedent moisture conditions (AMC) were not changed from the calibrated model in which AMC(II) or average conditions was adopted. Certainly, in very wet years, it could be argued that the wetter moisture conditions, for example AMC(III), might be applicable resulting in even larger discharge values than produced herein. Tropical storm Fay precipitation from 2008-08-20 to 2008-08-24 was replaced by the PMP event of $71 \mathrm{~cm}$ applied on 2008-08-21 with no precipitation assigned for the other $3 \mathrm{~d}$. Recompiling the calibrated model did provide for some challenges. Several small reservoirs in the headwaters of the upper basin actually become overtopped during the PMP event such that HEC-HMS inputs needed to be changed for these areas. For each of the problematic reservoirs, a hypothetical large overflow weir was added at the design crest to pass the discharge out of the reservoir. This of course was for simulation purposes only; in a real PMP event, it is quite possible that all of these reservoirs could fail due to overtopping flows. Once the debugging process was complete, simulated PMP discharges were reviewed at each of the six stream gauge locations discussed previously in this study. Figures 4 to 9 show the simulated flood events at each location as well as observed flows during the Fay event and calibration flows during the Fay event. Note that the US 192 gauge is also denoted as St. Johns River 20 in HECHMS. Similarly, the FL 520 gauge is also known as St. Johns River 35 while the inlet to Lake Harney is known as St. Johns River 52.

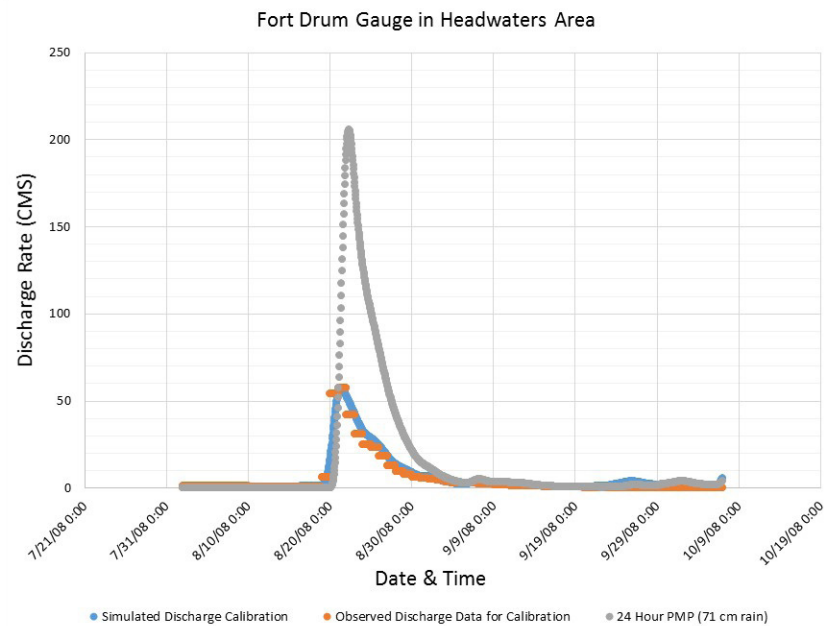

Figure 4 Simulation results for $24 \mathrm{~h}$ PMP event at Fort Drum outlet.

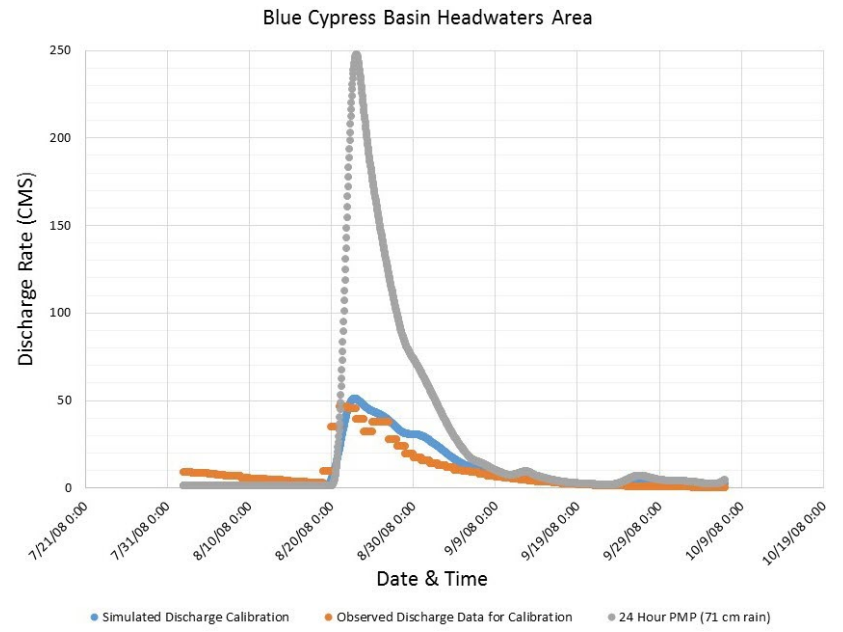

Figure 5 Simulation results for $24 \mathrm{~h}$ PMP event at Blue Cypress outlet.

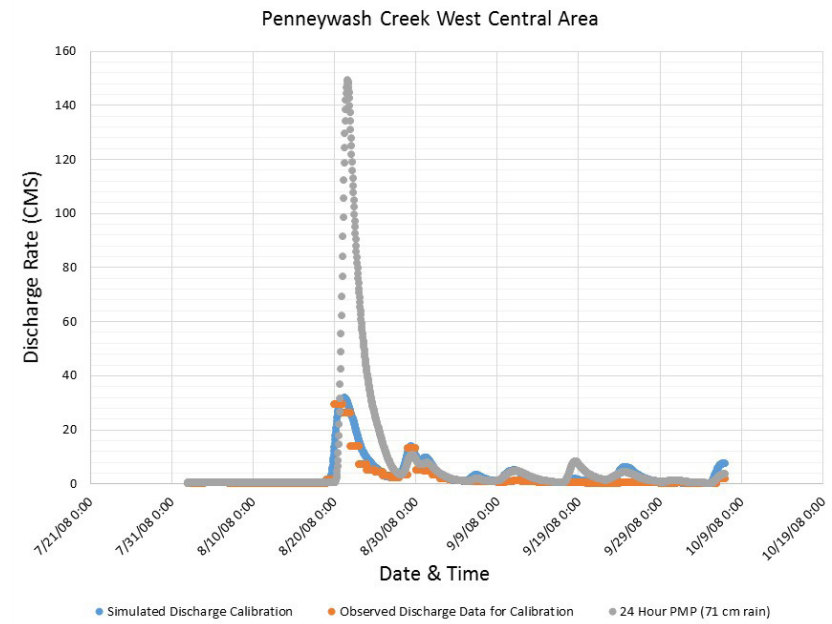

Figure 6 Simulation results for $24 \mathrm{~h}$ PMP event at Penneywash Creek outlet.

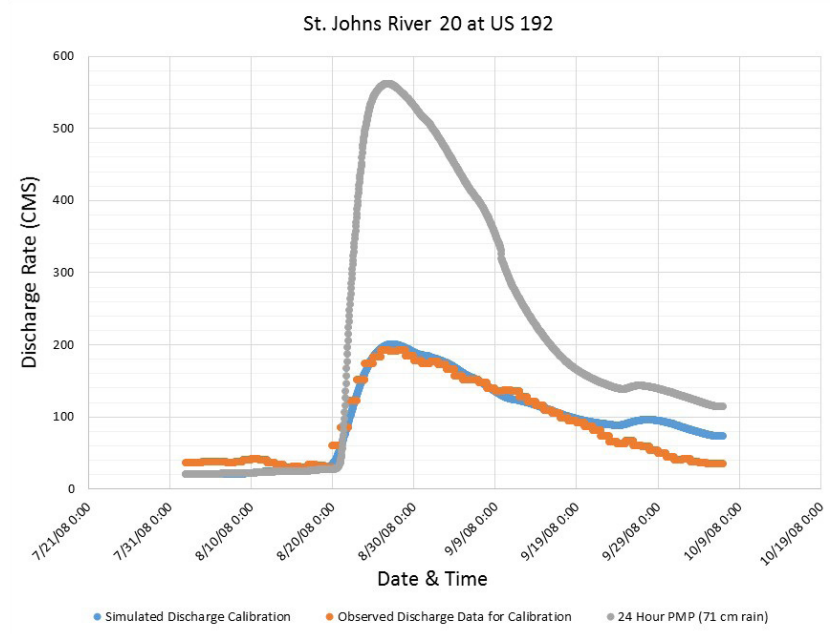

Figure 7 Simulation results for 24 h PMP event at US 192. 


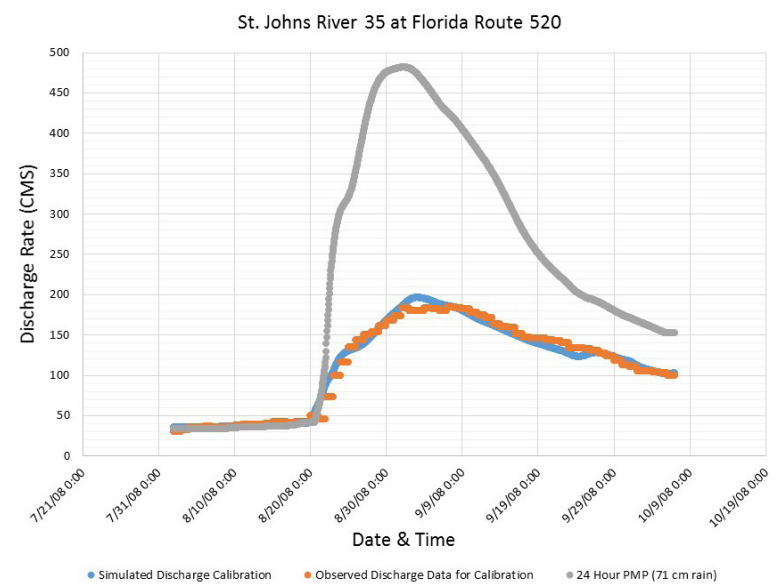

Figure 8 Simulation results for $24 \mathrm{~h}$ PMP event at FL 520.

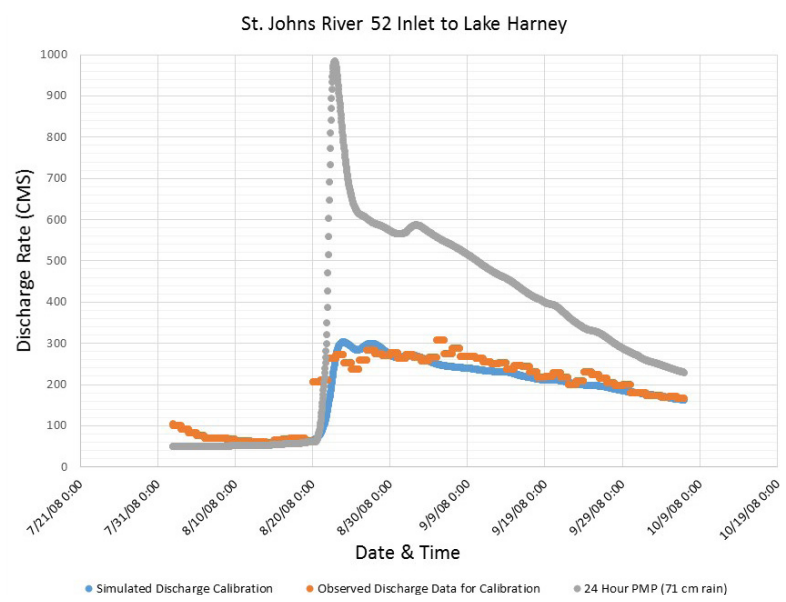

Figure 9 Simulation results for $24 \mathrm{~h}$ PMP event at inlet to Lake Harney.

A review of the figures reveals that the peak precipitation rates for the $24 \mathrm{~h}$ PMP event result in probable maximum flood (PMF) flow rates ranging from a low of $148 \mathrm{~m}^{3} / \mathrm{s}$ at the Penneywash Creek outlet to a high of $980 \mathrm{~m}^{3} / \mathrm{s}$ at the inlet to Lake Harney. These flow rates are $\sim 2.75$ times greater than tropical storm Fay peak flows along the St. Johns River main stem and $>4$ times greater for the smaller subbasins (Fort Drum, Blue Cypress and Penneywash Creek). It is also interesting to note that the recommended SJRWMD design PMP event (SJRWMD 2010) is smaller than that simulated herein. SJRWMD uses the $24 \mathrm{~h}$ duration PMP storm for design purposes within its regulatory boundaries with a 200 mile $^{2}\left(518 \mathrm{~km}^{2}\right)$ storm as the standard storm size with $78.74 \mathrm{~cm}$ of precipitation. Scaling this storm to the model domain size similar to the procedure outlined above results in a recommended design PMP precipitation event of $\sim 63 \mathrm{~cm}$ which is less than the hurricane Easy $24 \mathrm{~h}$ event. It is important to note that since the Three Forks Marsh Conservation Area is not included in the current model, the actual hydrographs (e.g. peak discharge rates) predicted using the model are likely a bit higher than would otherwise be observed if this important storage area was included. Additional simulations would be required to determine the degree of flood mitigation provided by the storage area; however, it is not anticipated to be significant at the PMF event.

\subsection{The $24 \mathrm{~h}$ PMP Event with Climate Change}

The $24 \mathrm{~h}$ PMP event with climate change forcing considered results in small increases in peak flow rates ranging from 3\% to $6 \%$ at different stations with peak flow at Lake Harney increasing to $1020 \mathrm{~m}^{3} / \mathrm{s}$. It should be noted that due to the small relative changes recorded, no additional figures were plotted for this particular scenario. Further study of climate change forcing is warranted as the possible changes in extreme events have not really been studied in any detail as yet.

\subsection{Two 100 y Events in Seven Days}

The last extreme precipitation events that were simulated with the calibrated model included a scenario whereby two 100 y recurrence interval precipitation events happened within 7 d. Perica et al. (2013) provide precipitation recurrence interval estimates from $5 \mathrm{~min}$ to $72 \mathrm{~h}$ duration up to a 1000 y return period. In reviewing 100 y precipitation totals for the upper basin study area, precipitation depths range from $\sim 27.5 \mathrm{~cm}$ to $33 \mathrm{~cm}$ with a median value of $\sim 30 \mathrm{~cm}$. Therefore, for ease of simulation development, a value of $30 \mathrm{~cm}$ was applied across the model domain on day 2 and day 5 of the same tropical storm Fay week using the August 2008 model calibration event. Essentially, the observed precipitation values from 2008-0821 to 2008-08-27 were replaced with the hypothetical precipitation with 2008-08-21 and 2008-08-24 each receiving $30 \mathrm{~cm}$ precipitation while the other days of that week were assigned $0 \mathrm{~cm}$ precipitation. In addition, no changes to AMC values were made for this model scenario, although it might be reasonably argued that a wetter than average condition could be appropriate after the first $100 \mathrm{y}$ precipitation event; nonetheless, this approach was not taken for this scenario. Figures 10 through 12 provide the hydrograph results over plotted with the previous PMP, calibration, and observed 2008 data discussed previously. The peak flood rates range from $\sim 131 \mathrm{~m}^{3} / \mathrm{s}$ to $676 \mathrm{~m}^{3} / \mathrm{s}$, or a bit more than twice those observed during tropical storm Fay in 2008. The results at the other three stations presented previously are similar in nature to Figures 10 to 12.

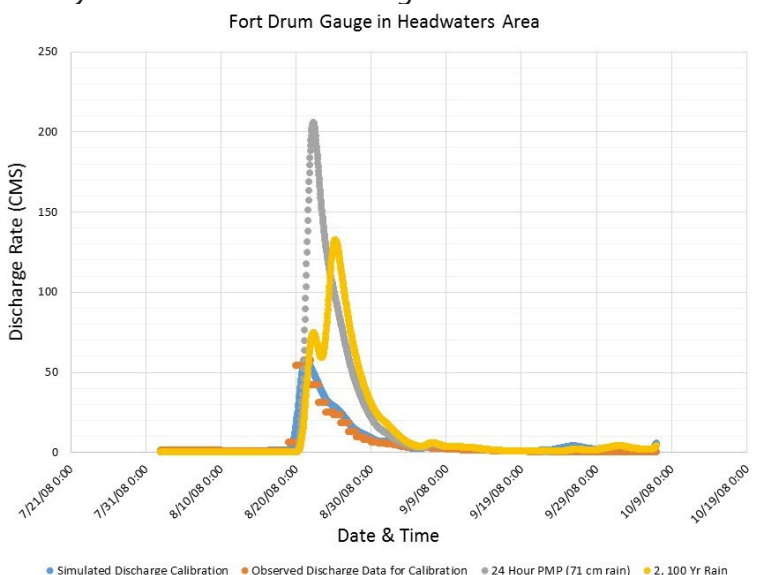

Figure 10 Simulation results for two $100 \mathrm{y}$ rain events in same week at Fort Drum outlet. 


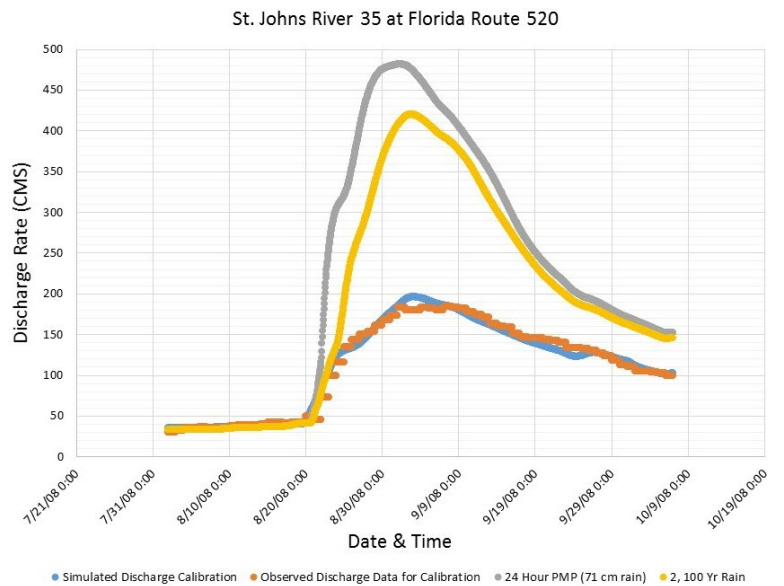

Figure 11 Simulation results for two $100 \mathrm{y}$ rain events in same week at FL 520.

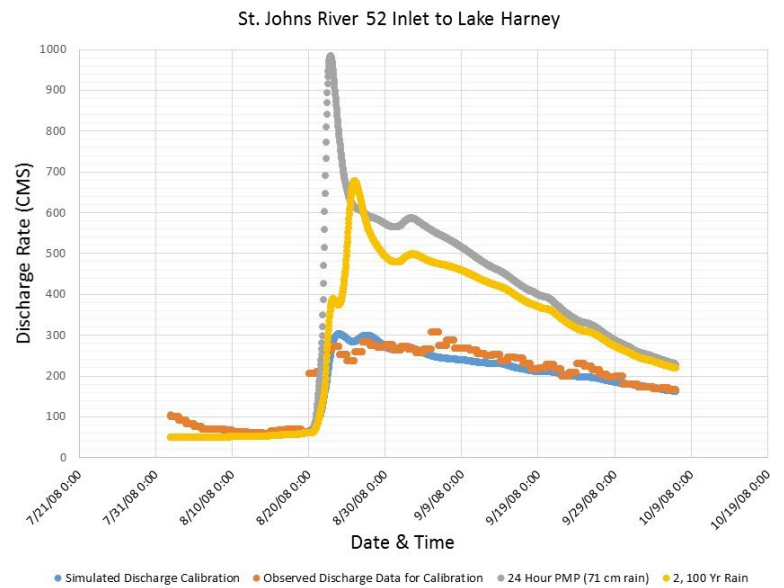

Figure 12 Simulation results for two $100 \mathrm{y}$ rain events in same week at inlet to Lake Harney.

\section{Conclusions}

This paper has discussed the overall development, calibration, and validation of a large HEC-HMS model of the upper basin and a portion of the middle basin of the St. Johns River in Northeast Florida. The calibrated and validated model was used to simulate the watershed response from three different extreme storm events. The largest of these, the PMP event, provided the largest hydrograph response and maximum expected flood flows in the model domain. The largest flood flow at the inlet of Lake Harney is predicted to be $\sim 980 \mathrm{~m}^{3} / \mathrm{s}$, which is about three times greater than flood flows observed during tropical storm Fay in 2008.

The second extreme event was simply a modification of the PMP event to include possible future climate change forcing that may further increase PMP flood flows by $3 \%$ to $6 \%$ with a $5 \%$ increase in precipitation. A final scenario that was simulated included the application of two 100 y precipitation events of $\sim 30 \mathrm{~cm}$ each during the same week. These predicted flood flows were more than twice those observed during tropical storm Fay. One important observation from the modeling effort was that a number of small reservoirs located in the upper basin may fail under these extreme loadings. These reservoirs include:

- BC East;

- Kensansville Lake;

- Tucker;

- Mary A Groves;

- Mary A. Groves Restoration; and

- Taylor Creek.

In addition, the outlet of Lake Harney also appeared to be subject to overtopping flows. All of these water control projects should be further investigated to determine their resiliency to manage extreme flood events without catastrophic failure.

\section{References}

Anderson, M., Z. Chen, M. Kavvas and A. Feldman. 2002. “Coupling HEC-HMS with Atmospheric Models for Prediction of Watershed Runoff." Journal of Hydrologic Engineering 7 (4): 312-8. https://doi.org/10.1061/(ASCE)1084-0699(2002).

Arnold, J. G. and P. M. Allen. 1993. "A Comprehensive Surface-Groundwater Flow Model." Journal of Hydrology 142 (1-4): 47-69.

Arnold, J. G. and N. Fohrer. 2005. "SWAT2000: Current Capabilities and Research Opportunities in Applied Watershed Modeling." Hydrologic Processes 19 (3): 563-72.

City and County of Sacramento. 1996. "Lag Time." In Drainage Manual Volume 2: Hydrology Standards, ch. 7. http://www.waterresources.saccounty.net/DrainageManual_Volume2/V2_Chap07.PDF.

Hackney, C., ed. 2015. St. Johns River Economic Study. Jacksonville, FL: University of North Florida Office of Research and Sponsored Programs.

Knebl, M. R., Z. L. Yanga, K. Hutchison and D. R. Maidment. 2005. "Regional Scale Flood Modeling Using NEXRAD Rainfall, GIS, and HEC-HMS/RAS: A Case Study for the San Antonio River Basin Summer 2002 Storm Event." Journal of Environmental Management 75:325-36. https://doi.org/10.1016/j.jenvman.2004.11.024.

Li, M. H. and P. Chibber. 2008. "Overland Flow Time of Concentration on Very Flat Terrains." Journal of the Transportation Research Board 2060:133-40. https://doi.org/10.3141/2060-15.

Luettich, R. A. and J. J. Westerink. 1991. "A Solution for the Vertical Variation of Stress, Rather Than Velocity, in a Three-Dimensional Circulation Model." International Journal for Numerical Methods in Fluids 12:911-28.

Nash, J. E. and J. V. Sutcliffe, 1970. "River Flow Forecasting Through Conceptual Models: Part I, A Discussion of Principles." Journal of Hydrology 10:282-90. 
Perica, S., D. Martin, S. Pavlovic, I. Roy, M. St. Laurent, C. Trypaluk, D. Unruh, M. Yekta and G. Bonnin. 2013. NOAA Atlas 14 Volume 9 Version 2, Precipitation-Frequency Atlas of the United States, Southeastern States. Silver Spring, MD: NOAA, National Weather Service.

Scharffenberg, W. A. and M. J. Fleming. 2010. Hydrologic Modeling System HEC-HMS User's Manual. Davis, CA: U.S. Army Corps of Engineers.

Schriener L. C. and J. C. Riedel. 1978. Probable Maximum Precipitation Estimates, United States East of the 105th Meridian. Washington, DC: U.S. Department of Commerce, National Oceanic and Atmospheric Administration and U.S. Department of the Army, Corps of Engineers. Hydrometeorological Report 51.

Sharifi, S. and S. M. Hosseini. 2011. "Methodology for Identifying the Best Equations for Estimating the Time of Concentration of Watersheds in a Particular Region." Journal of Irrigation and Drainage Engineering 137 (11): 712-9.

St. Johns River Water Management District (SJRWMD). 2010. Applicant's Handbook: Management and Storage for Surface Waters. Palatka, FL: St. Johns River Water Management District.
St. Johns River Water Management District (SJRWMD). 2014. Land Cover/Land Use 1994-95-SJRWMD [Map]. Palatka, FL: St. Johns River Water Management District.

Tancreto, A. E. 2015. Comparison of Hydrologic Model Performance Statistics Using Thiessen Polygon Rain Gauge and NEXRAD Precipitation Input Methods at Different Watershed Spatial Scales and Rainfall Return Frequencies. Jacksonville, FL: University of North Florida. Master's Thesis. http://digitalcommons.unf.edu/etd/584.

U.S. Army Corps of Engineers (USACE). 2000. Hydrologic Modeling System HEC-HMS. Davis, CA: USACE. Report No. CPD-74B.

U.S. Department of Agriculture Natural Resources Conservation Service. 2010. "Time of Concentration." In National Engineering Handbook, ch. 15. Washington, DC: U.S. Department of Agriculture.

U.S. Department of Agriculture Soil Conservation Service. 1972. National Engineering Handbook, Section 4, Hydrology. Washington, DC: U.S. Department of Agriculture.

Wang, W. C., K. W. Chau, C. T. Cheng and L. Qiu. 2009. "A Comparison of Performance of Several Artificial Intelligence Methods for Forecasting Monthly Discharge Time Series." Journal of Hydrology 374 (3): 294-306. 